\title{
SELECTED PROBLEMS OF THE VALUE APPRAISAL OF REAL ESTATE BUILT CONTRARY TO CONSTRUCTION LAW - PART I
}

\author{
Maria Zbylut-Górska, Adam Górski
}

\section{Summary}

The scope of the examination of the actual condition, and the examination of the legal status of real estate property has long raised practical doubts and dilemmas. In particular, the issue of the valuation expert's obligation to take into account irregularities in construction proceedings raises a number of reservations.

In the first part of the article, the concept of unauthorized construction works (performed without a building permit) is presented; the duties of the appraiser provided for in the Real Estate Management Act are listed; the consequences of unauthorized construction works performed without a building permit, and other defects in the construction process are described; as well as difficulties in determining whether a given object has in fact been unauthorizedly constructed. Examples of decisions and permits issued in the construction process and their significance for the property appraiser were discussed.

The second part of the article analyses the impact of the building permit on the price of the real estate property and discusses the scope of the obligation for the property appraiser to examine the compliance of the valued property with building regulations. Examples of bank's requirements for property appraisers will also be indicated, and the problem of the practical significance of clauses included in real estate appraisal reports will be presented. The discussion of all the above issues concludes with a summary.

As a rule, a real estate property appraiser is not a person authorized to assess whether a given object, in whole or in part, has been built or is being used in accordance with building regulations. The appraiser, due to the statutory duty to exercise special diligence appropriate to the professional nature of his or her activities, is required to collect and use all necessary and available data on the given real estate property. If a discrepancy is found in the analysed documentation, the appraiser should mention it in the report. The appraiser is neither entitled nor obliged to determine the causes of the discrepancies. The indicated circumstances justify the inclusion in the report a clause that the valuation of the property in question may change due to discrepancies revealed, or proceedings being conducted. Failure to provide relevant information and reservations may justify the expert's liability under the applicable provisions of the Civil Code.

\section{Keywords}

real estate appraisal $\bullet$ Construction Law $\bullet$ unauthorized construction works (conducted without a building permit) $\bullet$ building permit 


\section{Introduction}

The scope of the examination of the actual condition (current status), and the examination of the legal status of real estate property has long raised practical doubts and dilemmas. In particular, the issue of the expert's obligation to take into account irregularities in construction proceedings raises a number of reservations.

In the first part of the article, the concept of unauthorized construction works (performed without a building permit) is presented; the duties of the appraiser provided for in the Real Estate Management Act are listed; the consequences of unauthorized construction works performed without a building permit, and other defects in the construction process are described, as well as difficulties in determining whether a given object has in fact been unauthorizedly constructed. Examples of decisions and permits issued in the construction process and their significance for the property appraiser are discussed. The observations are concluded with a summary.

\section{Concept of unauthorized construction (conducted without building permit) - general observations}

Under the provisions of Article 48 of Construction Law [1], we are dealing with unauthorized construction when a building or a part thereof is under construction or has been constructed without the required building permit or notification, or violates a specific objection by the competent authority [2]. The problem of the impact of unauthorized construction on estimating the value of real estate property has been noticed in judicial practice [3]. The jurisprudence may state that an expert in the field of real estate appraisal does not examine the legality of conducting construction works [4]. As part of this view, it is pointed out that neither the provisions of the Real Estate Management Act [5] nor the provisions of the Council of Ministers Regulation on the valuation of real estate property and the preparation of an appraisal report [6] impose on the real estate property appraiser the obligation to examine and state, whether the structures on the land being valued had been built on the basis of building permits required by law or relevant notifications. It was also pointed out that, at present, the question of the possible existence of so-called unauthorized construction (structures built without a permit or authorisation) within the real estate property cannot have a direct bearing on the assessment of the correctness of the valuation made by the appraiser [7]. One should agree with the statement that it is not the task of a real estate property appraiser to assess whether a specific object has been constructed without authorization, but rather it is the competency of building supervision authorities and possibly experts possessing specialist knowledge in the field. Determining whether a given building is a case of unauthorized construction is extremely complicated. For example, the determination of the lack of building's compliance with technical and building regulations does not necessarily mean unauthorized construction. It is possible that the investor could have obtained consent in this regard, pursuant to Article 9 of the Construction Law, allowing an exception or waiving the obligation to comply with these provisions 
[8] (see, for example, the Summary of Regulations). On the other hand, it should be noted that even the determination that the construction of the building remained in accordance with the construction design does not guarantee that the building had been built in accordance with the regulations, because, for instance, the solutions adopted in the design may violate the provisions on fire protection [9].

Anticipating further considerations, it should be stated at this point that the abovementioned opinion - namely that any defects in real estate property, related to deficiencies pertaining to the construction process or use of the property remain entirely outside the scope of interest of the real estate property appraiser - does not hold.

\section{Administrative decisions issued during the construction process and their significance to real estate property appraiser}

In the construction process, apart from the building permit (or construction notification), a number of other administrative decisions may be issued depending on the scale and type of the investment project. Among others, these may include a decision on land development and building conditions, water law permits, the so-called environmental decisions, etc. However, the highest importance should be assigned to the last action carried out before the building authorities, that is obtaining the occupancy permit, or failure to raise objections by the building inspection authorities to the notification of the completion of construction, as in Articles 54, 55 [1]. The jurisprudence indicates that if the investor has departed from the terms of the building permit, he cannot effectively submit a notice of completion of the construction, nor can he apply for the occupancy permit [10], [11]. The requirement to verify decisions prior to the authority's final determination that the constructed building can be occupied would contradict the principle expressed in Article 16 [12] (KPA), i.e. the presumption that final administrative decisions are correct [13]. The case law emphasizes that the decision on the occupancy permit determines that from a technical point of view, the completed works can be accepted [14]. Therefore, it is completely pointless to question or analyse administrative decisions or agreements made prior to the occupancy (using the facility).

A significant period of time may elapse from the time of commencement of use (occupancy) and changes in the actual state of the object under valuation cannot be excluded. The scope of these works or changes may vary; from on-going maintenance work to, for example, a major reconstruction of the object in question. Therefore, it is reasonable to distinguish, in accordance with the relevant Construction Law, between works carried out in terms of construction, reconstruction, or mere renovation. In accordance with Article 3 clause 6 [1], construction means the execution of a building object in a specific place, as well as the reconstruction, extension or adding a superstructure to a previously built object. Reconstruction is the performance of construction works, as a result of which there is a change in the utility or technical parameters of the existing building, with the exception of characteristic parameters, such as: volume, building area, height, length, width or number of floors; in the case of roads, changes in characteristic parameters are allowed in a scope that does not require changing the 
lane boundaries - see: Article 3 clause 7a [1]. In turn, the concept of renovation covers the performance of construction works in an existing building, consisting of restoration of the original condition and not constituting on-going maintenance, whereas the use of construction products other than used in the original condition is allowed (Article 3 clause 8) [1]. Without going into the details of the cited definitions, it should be noted that without specialist knowledge it might be problematic to qualify the on-going construction works, see e.g. [15], [16], [17], [18]. This problem will be even greater when the works had been completed, and in particular in the situation where any detailed or as-built documentation is lacking, as is often the case in practice. In addition, in accordance with Article 29 of the Construction Law, some of the reconstruction and renovation works do not require a permit or notification to the relevant authorities. The distinction between construction versus reconstruction or renovation is important, because obtaining an occupancy permit or no objection by the authority as a result of notifying the subject of the completion of construction is not required for the use of a building that had been rebuilt or renovated, even when it required a permit for construction [19]. Even after determining that the works constituted construction within the meaning of the Construction Law and were carried out without obtaining a building permit, or without appropriate notification, another problem is the fact that, in the light of applicable regulations, the consequences of unauthorized construction will depend on the date it was committed. The doctrine emphasizes that for a building erected without a construction permit (or without notification), three different kinds of legal status may apply - depending on the date when the unauthorized construction was committed - the provisions of Article 37 of the Construction Law of 1974, provisions of Article 48 of the Construction Law in its original wording, or provisions of Article 48 of the Construction Law in the currently binding version [20].

The question is whether these circumstances remain within the scope of interest of the real estate property appraiser. The answer to this question must be preceded by an analysis of the appraiser's obligations under the Real Estate Management Act.

\section{Obligation of property appraiser in the light of the Real Estate Management Act}

According to the Real Estate Management Act, the appraiser is obliged to perform his or her activities with special diligence appropriate to the professional nature of these activities (Article 175 of the Real Estate Management Act). Numerous judgments indicate that the concept of "special diligence" within the meaning of the said provision is the closest in content to the concept of due diligence within the meaning of Article 355 clauses 1 and 2 [21] of the Civil Code see e.g. [22], [23], [24]. Within the doctrine and jurisprudence, we also encounter the view that special diligence should be understood as a stricter benchmark criterion, which requires special behaviour that befits a professional. Special diligence is therefore a more extensive term than due diligence [25], [26]. Regardless of the accepted understanding of the concept of "special diligence", it is undeniable that the appraiser must maintain at least "due diligence" in the perfor- 
mance of his or her duties. In the light of the Supreme Court's well-founded view, due diligence, determined while taking into account the professional nature of business operations, also includes knowledge of applicable law and its consequences in the field of business activity [27], [28], [29], [30].

Pursuant to Article 56 of the Regulation on the valuation of real estate and the preparation of an appraisal reports of September 21,2004, a description of the condition of the property, is a necessary element of each real estate appraisal report, among others.

In the light of Article 4 clause 17 of the Real Estate Management Act, the status of the real estate property should be understood as reflecting its state of development, legal status, technical and operational status, the degree to which it has been equipped with technical infrastructure, as well as the state of the surroundings of the real estate property, including the size, nature and degree of urbanization of the place where the given real estate is located. The concept of legal status raises some doubts. In practice, the legal status of real estate is limited to the analysis of the land and mortgage register, or to the indication of entities with real rights to the property. The jurisprudence indicates that the description of the legal status is practically limited to citing entries arising from land and mortgage registers and land records, see: [31], [32]. In addition, in Article 113 of the UoGN [5], the legislator pointed out that the unregulated legal status applies to real estate properties in relation to which - due to the lack of the land and mortgage register, collection of documents or other sources - it is not possible to determine persons who hold property rights. It should also be noted that in civil law, physical and legal defects of goods are distinguished (Article 556 et seq.) [21]. A physical defect consists in the incompatibility of the sold item with the contract (Article 556'1) [21]. The jurisprudence emphasizes that unauthorized construction should be treated as a physical defect within the meaning of the indicated provisions [33], [34]. The doctrine indicates that the revocation of the building permit will be treated as a legal defect [35]. Another legal defect is the limitation to the use or disposal of things arising from a decision or ruling of the competent authority as in Article 556'3 [21]. We should remember, however, that in the light of applicable regulations, the use of the completed building (built without authorization) cannot be prohibited [36]. Only in the event of a change in the use of the building or part thereof without the required notification, the building supervision authority may suspend the use of the building or part thereof - see: Article 71a [1]. Thus, the issue of distinguishing between a physical defect and a legal defect may raise numerous doubts. Other views presented in case law should also be cited. For example, the Supreme Administrative Court in its judgment of 18 March 2015 [37] indicated that the legal status includes the analysis of regulations contained in local spatial development plans in terms of determining the land use designation. Other rulings indicate that another legal defect of the building is the lack of occupancy permit [38].

Practitioners also point out the need to examine the compliance of the built property with building regulations as one of the elements of the legal status examination [39].

In the light of the above-mentioned views, it should be stated that it is questionable whether the concept of legal status also includes the compliance of the building with 
building regulations, whereas this issue is not uniformly included in the case law and may raise doubts.

Regardless of the accepted understanding of the concept of legal status, the fact of unauthorized construction, or for instance lack of occupancy permit, will affect the price of the estimated property. For example, the Court of Appeals in Kraków indicated that if it is possible to obtain an occupancy permit after completing the necessary documentation, the lack of such an authorization reduces the value of the acquired right only by the costs that is necessary to obtain that permit [40].

\section{Consequences of unauthorized construction and other defects of the construction process}

Assuming that the defects of the construction process will affect the price of the estimated real estate property requires an explanation of the consequences of these irregularities, provided in particular under the Construction Law. And thus, in the case of unauthorized construction, the authority orders the demolition of such a building or part of it, unless it is possible to legalize it (see: Articles 48-49b of the Construction Law). In the case of other works carried out without authorization, the regulations provide for corrective proceedings specified in Article 50-51 of the Construction Law [41]. A change in the use (functional designation) of a building or part thereof without the required notification also has far-reaching consequences, even including an injunction to restore the previous use of such a building (see: Article 71a) [1]. In each of these cases, regulating the compliance of the building with building regulations will involve the necessity of incurring appropriate expenses (e.g. verification fees, costs of adaptation works, costs of necessary documentation, etc.). The scope of such expenses may be difficult to estimate - because, for example, when all the work has been carried out correctly and there is no need to adapt the changes to technical and building regulations, the costs will be lower. In such a situation, the authority will issue a decision waiving the imposition of certain obligations provided for in the articles of Construction Law [42].

Determining that a given real estate property constitutes unauthorised construction is in whole or in part, or that it does not have the required occupancy permits also bears on the possibility of comparing that property with other real estate properties. In accordance with Article 4 clause 16 [5] "similar real estate property" means a property that is comparable to the property being the subject of the valuation, due to its location, legal status, purpose, functional designation (use), and other features affecting its value. Regardless of whether we consider compliance with building regulations as an element of legal status, it will be a feature that affects the value of real estate property.

\section{Conclusions}

The stated fact of unauthorized construction, or - for instance - the lack of occupancy permit, will affect the price of the estimated real estate property. In each case, regulat- 
ing the compliance of the building condition with building regulations will involve the necessity of incurring appropriate expenses. The scope of such expenses may be difficult to estimate because, for example, when all the work has been carried out correctly and there is no need to adapt the changes that had been introduced to the current technical and building regulations, the costs will be lower. The second part of the article shall analyse the impact of the building permit on the price of the real estate property, and discuss the scope of the property appraiser's obligation to examine the compliance of the valued property with building regulations. Exemplary requirements for property appraisers on the part of banks will also be indicated, and the problem of the practical significance of clauses included in appraisal reports will be presented.

\section{References}

[1] Ustawa z dnia 7 lipca 1994 r. - Prawo budowlane, Dz. U. Nr 89, poz. 414 ze zm.

[2] Prawo budowlane. Komentarz. Zygmunt Niewiadomski, Tomasz Asman, Jędrzej Dessoulavy-Śliwiński, Elżbieta Janiszewska-Kuropatwa, Alicja Plucińska-Filipowicz, Jerzy Siegień, 2018, komentarz do art. 48, Legalis.

[3] Opinia Stowarzyszenia Sędziów Polskich „Iustitia” do projektu rozporządzenia Ministra Sprawiedliwości dotyczącego opisu i oszacowania nieruchomości z roku 2016. https:// www.iustitia.pl/opinie/1271-ozc2 (accessed: 06.08.2019).

[4] Wyrok Sądu Okręgowego w Nowym Sączu z dnia 4 marca 2014 r., Sygn. akt I C 128/12. https://www.saos.org.pl/judgments/content/145748.html, accessed: 06.08.2019).

[5] Ustawa z dnia 21 sierpnia 1997 r. o gospodarce nieruchomościami, Dz.U. Nr 115, poz. 741 ze zm.

[6] Rozporządzenie Rady Ministrów w sprawie wyceny nieruchomości i sporządzania operatu szacunkowego z dnia 21 września 2004 r., Dz.U. Nr 207, poz. 2109 ze zm.

[7] Wyrok Wojewódzkiego Sądu Administracyjnego w Warszawie z dnia 24 kwietnia 2012 r., I SA/Wa 1972/11, Legalis.

[8] Zestawienie przepisów, od których można uzyskać zgodę na odstępstwo od obowiązujących przepisów techniczno-budowlanych. https:/www.biznes.gov.pl/pl/publikacje/ 3768-zestawienie-przepisow-od-ktorych-mozna-uzyskac-zgode-na-odstepstwo-odobowiazujacych-przepisow-techniczno-budowlanych (accessed: 06.08.2019).

[9] Wspólne Stanowisko Komendanta Głównego Państwowej Straży Pożarnej oraz Głównego Inspektora Nadzoru Budowlanego z dnia 11 grudnia 2014 r. https://www.gunb.gov.pl/ (accessed: 06.08.2019).

[10] Wyrok Naczelnego Sądu Administracyjnego z dnia 8 czerwca 2018 r., II OSK 1697/16, Legalis.

[11] Wyrok Naczelnego Sądu Administracyjnego z dnia 20 listopada 2009 r. II OSK 1049/09, Legalis.

[12] Kodeks postępowania administracyjnego z dnia 14 czerwca 1960 r., Dz. U. Nr 30, poz. 168 ze zm.

[13] Kodeks postępowania administracyjnego. Komentarz prof. zw. dr hab. Roman Hauser, prof. zw. dr hab. Marek Wierzbowski, 2018, komentarz do art. 16 KPA, Legalis.

[14] Wyrok Naczelnego Sądu Administracyjnego - Ośrodek zamiejscowy w Bydgoszczy, z dnia 4 czerwca 2003 r., SA/Bd 372/03, Legalis.

[15] Wyrok Naczelnego Sądu Administracyjnego z dnia 21 lutego 2018 r., II OSK 1093/16 Legalis. 
[16] Wyrok Wojewódzkiego Sądu Administracyjnego z siedzibą w Bydgoszczy z dnia 10 stycznia 2018 r., II SA/Bd 847/17, Legalis.

[17] Wyrok Naczelnego Sądu Administracyjnego z dnia 9 stycznia 2018 r., II OSK 750/16, Legalis.

[18] Wyrok Wojewódzkiego Sądu Administracyjnego z siedzibą w Bydgoszczy z dnia 28 sierpnia 2018 r., II SA/Bd 76/18, Legalis.

[19] Prawo budowlane. Komentarz Zygmunt Niewiadomski, Tomasz Asman, Jędrzej Dessoulavy-Śliwiński, Elżbieta Janiszewska-Kuropatwa, Alicja Plucińska-Filipowicz, Jerzy Siegień, 2018, komentarz do art. 54, Legalis.

[20] Prawo budowlane. Komentarz Zygmunt Niewiadomski, Tomasz Asman, Jędrzej Dessoulavy-Śliwiński, Elżbieta Janiszewska-Kuropatwa, Alicja Plucińska-Filipowicz, Jerzy Siegień, 2018, komentarz do art. 48, Legalis.

[21] Ustawa z dnia 23 kwietnia 1964 r. - Kodeks cywilny, Dz.U. Nr 16, poz. 93 ze zm.

[22] Wyrok Naczelnego Sądu Administracyjnego z dnia 29 sierpnia 2017 r., II GSK 3379/15, Legalis.

[23] Wyrok Naczelnego Sądu Administracyjnego z dnia 26 października 2018 r., II GSK 904/18, Legalis.

[24] Wyrok Naczelnego Sądu Administracyjnego z dnia 8 grudnia 2016 r., II GSK 1881/15, Legalis.

[25] Wyrok Sądu Rejonowego dla Wrocławia-Krzyków, Wydział I Cywilny z dnia 14 maja 2013 r. Sygn. akt I C 983/12. http://orzeczenia.wroclaw-krzyki.sr.gov.pl/content/\$N/155025450000503_I_C_000983_2012_Uz_2013-07-01_001 (accessed: 06.08.2019).

[26] Ustawa o gospodarce nieruchomościami. Komentarz Jacek Jaworski, Arkadiusz Prusaczyk, Adam Tułodziecki, Marian Wolanin, 2017, komentarz do art. 175, Legalis.

[27] Wyrok Sądu Najwyższego - Izba Cywilna - z dnia 17 sierpnia 1993 r., III CRN 77/93 OSNC $1994 \mathrm{nr}$ 3, poz. 69, Legalis.

[28] Kodeks cywilny. T. I. Komentarz. Art. 1-44910 red. prof. dr hab. Krzysztof Pietrzykowski, 2018, komentarz do art. 355, Legalis.

[29] Kodeks cywilny. Tom II. Komentarz. Art. 353-626, red. prof. dr hab. Maciej Gutowski, 2019, komentarz do art. 355, Legalis.

[30] Kodeks cywilny. Komentarz. Red. prof. dr hab. Edward Gniewek, prof. dr hab. Piotr Machnikowski, 2017, komentarz do art. 355, Legalis.

[31] Wyrok Naczelnego Sądu Administracyjnego z dnia 26 września 2018 r., II GSK 1234/18, Legalis.

[32] Wyrok Naczelnego Sądu Administracyjnego z dnia 6 kwietnia 2018 r., II GSK 414/18, Legalis.

[33] Wyrok Sądu Apelacyjnego w Szczecinie - I Wydział Cywilny - z dnia 27 listopada 2014 r., I ACa 558/13, Legalis.

[34] Wyrok Sądu Okręgowego w Płocku, I Wydział Cywilny z dnia 16 czerwca 2017 r., Sygn. akt I C 1066/15. https://www.saos.org.pl/judgments/303636 (accessed: 06.08.2019).

[35] Szlęzak Andrzej, glosa do Wyroku Sądu Najwyższego z dnia 31 maja 2017 r., V CSK 506/16. Orzecznictwo Sądów Polskich 2018 nr 12.

[36] Krzyżanowska Anna, Prawo budowlane z luką dla nieuczciwych: Nie można zakazać użytkowania samowoli budowlanej. https://prawo.gazetaprawna.pl/artykuly/924579,prawo-budowlane-samowola-budowlana.html 2016 r. (accessed: 06.08.2019).

[37] Wyrok Naczelnego Sądu Administracyjnego z dnia 18 marca 2015 r., I OSK 1684/13, Legalis.

[38] Wyrok Sądu Apelacyjnego w Krakowie - I Wydział Cywilny - z dnia 29 listopada 2016 r. Sygn. akt I ACa 1668/16. http://orzeczenia.krakow.sa.gov.pl/content/\$N/152000000000503_I_ Aca_001668_2016_Uz_2016-11-29_001 (accessed: 06.08.2019). 
[39] Stanek-Sobczak Magdalena, Księga wieczysta: jak sprawdzić nabywaną nieruchomość. https://www.rp.pl/artykul/943559-Ksiega-wieczysta--jak-sprawdzic-nabywana-nieruchomosc.html 2012 r. (accessed: 06.08.2019).

[40] Wyrok Sądu Apelacyjnego w Krakowie - I Wydział Cywilny - z dnia 29 listopada 2016 r. Sygn. akt I ACa 1668/16. http://orzeczenia.krakow.sa.gov.pl/content/\$N/152000000000503_I_ ACa_001668_2016_Uz_2016-11-29_001 (accessed: 06.08.2019).

[41] Wyrok Wojewódzkiego Sądu Administracyjnego z siedzibą w Kielcach z dnia 26 stycznia 2011 r., II SA/Ke 767/10, Legalis.

[42] Wyrok Wojewódzkiego Sądu Administracyjnego z siedzibą w Olsztynie z dnia 11 września 2018 r., II SA/Ol 318/18, Legalis.

Dr inż. Maria Zbylut-Górska

Uniwersytet Rolniczy w Krakowie

Katedra Geodezji

30-149 Kraków, ul. Balicka 253a

e-mail: m.zbylut-gorska@urk.edu.pl

ORCID: 0000-0003-4436-8248

Dr Adam Górski, adwokat

30-225, Kraków, al. Panieńskich Skał 2 